\title{
AN IMPROVED PROTOCOL FOR NATURAL CONVECTIVE DRYING OF PUMPKIN
}

\author{
Hakim Semai, Amor Bouhdjar*, Aissa Amari
}

Renewable Energy Development Centre (CDER), Solar Thermal and Geothermal Energy Division, 16340 Bouzaréah Algiers, Algeria

\begin{abstract}
The most effective way to preserve agricultural product is drying. However, vegetable drying is an energy-consuming procedure. Convective drying is the mode considered in this work. The study intends to explore a new way of pumpkin drying, which reduces drying time and minimizes heat consumption. The study considers pumpkin thin slices and pumpkin samples with cubic shape. The samples were subjected to free convection airflow at different temperatures $\left(40{ }^{\circ} \mathrm{C}, 46^{\circ} \mathrm{C}, 52{ }^{\circ} \mathrm{C}\right.$, and $\left.60{ }^{\circ} \mathrm{C}\right)$ for each run. A varying airflow temperature was also considered. Airflow velocity was generated by buoyancy forces for each temperature. Drying curves were plotted and fitted to the widely used thin-layer drying models. The modified Page model came out as the best-fitted model. The effective diffusivity coefficient was determined for each case using the slope moisture curve. It appeared that diffusivity was high and drying time was short, for high temperature. Drying processes for slice configuration and cube configuration showed that the latter was more efficient. When applying the regime of increasing temperatures to the cubic samples, data analysis showed that effective diffusivity was higher during the third step in comparison to all the other drying temperatures and the total drying time was similar to that obtained at drying regime on high temperature. With this procedure, the final consumed energy was much less and the time was shorter.
\end{abstract}

Key words: free airflow, energy optimization, sample configuration, vegetable, Page model, diffusivity

\section{INTRODUCTION}

Pumpkin (Cucurbita moschata) is a seasonal product traditionally used in human food as well as in medicine. It is widely consumed around the world as a fruit or as a vegetable. It is rich in vital antioxidants, and vitamins $\mathrm{A}, \mathrm{C}$, $\mathrm{B}_{12}$ and $\left.\mathrm{E}\right)$. Pumpkin is produced all over the world. Fresh pumpkins are very sensitive to microbial spoilage because of their high moisture content ( $\sim 90 \%$ w/w wet basis) (Roongruangsri \& Bronlund, 2015), requiring alternative preservation way to extend their shelf life. Drying helps reduce the water activity, thereby, increase its shelf life. So drying process is important for both preservation and transformation of the material. Drying reduces the transportation cost since it reduces the fruit weight. Storage and transportation of such products do not require any cooling (Kocabiyik, 2010). The production of dried food in a relatively short time, while maintaining nutritional and sensorial characteristics, is a challenge. There are many different methods to 
dry vegetables such as vacuum, convective, spray and freeze-drying. Each method produces products of different quality and has different costs (Arévalo-Pinedo \& Murr, 2007; Doymaz, 2007; Perez \& Schmalko, 2009; Nawirska, Figiel, Kucharska, Sokol-Letowska \& Biesiada 2009; Tunde-Akintunde \& Ogunlakin, 2013). Some authors used an intermittent microwave convective drying method which, according to these authors, improves the physical, nutritional, and chemical characteristics of the product (Esturk \& Soysal, 2010; Bantle, Käfer \& Eikevik, 2013). Thickness, drying temperature, power of microwave and pretreatment of a product are studied in convective, vacuum and microwave drying techniques to determine the effective moisture diffusivity coefficient and to choose the best fitting mathematical model (Süfer, Sezer \& Demir, 2017). Hot convective air drying appears to be, economically, the most appropriate technique mainly because of easy operation and faster drying rates. Drying is an energyconsuming procedure and it is imperative to find out the optimum drying conditions for economical operation. Drying kinetics is the most important information needed for dryer simulation and design. Previous works on pumpkin drying have considered neither natural or free convective airflow nor the temperature variation effect on the process. Often in solar drying, the convective airflow depends on solar radiation. The objective of the study was to simulate this phenomenon i.e. solar dry- ing, which means evolving temperature during the whole process. To sum up, this study aimed at finding out a new procedure to dry pumpkin, which preserves product quality, shortens drying time, and reduces energy consumption. Two ways are considered; the first one is in selecting from two sample configurations, a slab and a cube. The second one is in comparing drying at constant airflow temperature to drying in a process with increasing airflow temperature. All considered processes are undertaken under natural convection airflow.

\section{MATERIALS AND METHODS}

\section{Sample preparation}

Pumpkin bought in a local market was peeled and had the seeds removed. Samples were prepared from the pulp. Pumpkin samples of the first configuration were of parallelepiped shape $(5 \mathrm{~mm} \times 100 \mathrm{~mm} \times 50 \mathrm{~mm})$ suspended just above the tray. In the second configuration, the samples were cube-shaped with $10 \mathrm{~mm}$ edges.

\section{Convective drying procedure}

A laboratory experimental set-up consisting of a heat source and a chimney generates hot convective airflow (Bouhdjar et al., 2020). Samples were put on a $20 \mathrm{~cm}$ perforated circular tray. Buoyancy forces generate airflow. The hot source was regulated to have the chosen temperature. The sample container was $170 \mathrm{~cm}$ above the heat source to avert any radiation impact (Figure 1).

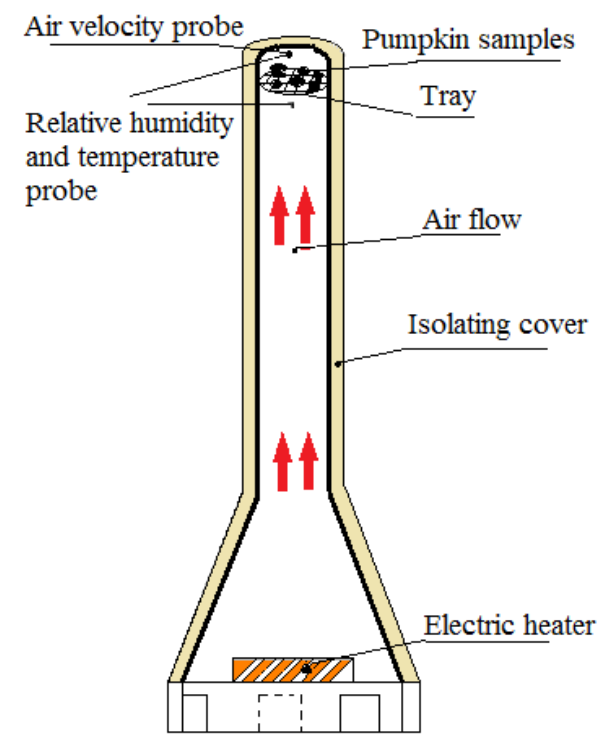

Figure 1. Schematic view of the drying set-up used for pumpkin drying 
The air velocity was dependent on airflow temperature, chimney height and friction forces. Friction forces tended to diminish along the drying process of samples. While the air velocity augments, the temperature will diminish. Therefore, power should be added to keep the fixed temperature. Throughout the process, usually, the velocity is increased since friction forces are diminished (they are the only parameter that changes throughout the process). The air is heated while flowing through the heat source. Air temperature is controlled and regulated ahead of the tray.

Airflow characteristic such as velocity was measured downstream using a digital anemometer having a $0.1 \mathrm{~m} / \mathrm{s}$ resolution and a $3 \%$ accuracy. A digital combined probe $\mathrm{CHY} 722$ was used to measure, ahead of the tray, the temperature and the relative humidity. It had an accuracy of $0.5^{\circ} \mathrm{C}$ for the temperature, and $2.5 \%$ for the relative humidity. Denver instrument balance with an accuracy of $0.01 \mathrm{~g}$ was used to weigh samples. The parallelepipedshaped samples were suspended in the chimney of $110 \mathrm{~mm}$ in diameter, above the tray. Air flows along the largest dimension. The cubic samples were placed as one layer on a $110 \mathrm{~mm}$ diameter circular tray located in the chimney (Figure 1). To facilitate the analysis, the same initial pumpkin mass was used in all runs, which was $104 \mathrm{~g}$ for the slices and $74 \mathrm{~g}$ for the cubes. At least three runs were performed for every case to assure the same environmental conditions existed.

During the experiment, the pumpkin samples were weighed every twenty minutes. Although we might have considered drying completed when three consecutive weight measurements remained unchanged, the process was continued for a longer time for analysis purposes. Five temperatures were considered i.e. $40{ }^{\circ} \mathrm{C}$, $46{ }^{\circ} \mathrm{C}, 52{ }^{\circ} \mathrm{C}, 56.5{ }^{\circ} \mathrm{C}$ and $60{ }^{\circ} \mathrm{C}$ for constant temperatures and a stepwise variable temperature regime $\left(40{ }^{\circ} \mathrm{C}, 46^{\circ} \mathrm{C}, 52^{\circ} \mathrm{C}\right.$, and $\left.60{ }^{\circ} \mathrm{C}\right)$ during the different experiments. At the variable temperature regime, $40{ }^{\circ} \mathrm{C}$ temperature was maintained during the first hour, $46{ }^{\circ} \mathrm{C}$ during the second hour, $52{ }^{\circ} \mathrm{C}$ for the third hour, and $60^{\circ} \mathrm{C}$ during the remaining time.

In solar drying systems, temperatures evolve during the whole process and they do not exceed $70{ }^{\circ} \mathrm{C}$ for a continuous flowing fluid beginning with temperature, which might be lo- wer than $40{ }^{\circ} \mathrm{C}$. Therefore, the test temperatures, which we can run continuously and assure a continuous process, were chosen in the above range. However, the results might as well be implemented in conventional industrial processes.

\section{Governing Equations}

Moisture movement in agricultural products during drying is due to a combination of different mechanisms, mainly liquid diffusion, capillary flow and vapour diffusion. These mechanisms can be lumped together into a diffusion-like equation (Crank, 1979; Crapiste, Whitaker \& Rotstein, 1988). Considering a 3D diffusion, a mass balance over a volume element generates the differential equation governing the phenomenon, in the following form:

$$
\frac{\partial M}{\partial t}=\frac{\partial}{\partial x}\left(D_{e x} \frac{\partial M}{\partial x}\right)+\frac{\partial}{\partial y}\left(D_{e y} \frac{\partial M}{\partial y}\right)+\frac{\partial}{\partial z}\left(D_{e z} \frac{\partial M}{\partial z}\right)(1)
$$

In writing down this equation, we assumed that physical properties are uniform and constant over the whole body during phase change.

$\mathrm{M}$ is the moisture content $(\mathrm{kg}$ water $/ \mathrm{kg}$ dry matter), $\mathrm{x}, \mathrm{y}$, and $\mathrm{z}$ are the moisture transfer paths in each direction, $t$ is the time and $D_{\text {en }}$ is the effective moisture diffusivity coefficient in the $n$-direction $(n=x, y, z)$. Since we considered uniform physical properties, we have $D_{e x}=D_{e y}=D_{e z}$ (homogeneous material). However, it should be noted that, although we assumed constant properties, the effective diffusivity coefficient $\left(D_{\text {eff }}\right)$ varies with product structure and moisture content. Our purpose is to compare two pumpkin sample configurations going through a drying process in the same environment. The first configuration consists a slab of the material of $2 l$ thickness. Water diffusion is dominating through the thickness. The mass balance equation is reduced to:

$\frac{\partial \mathrm{M}}{\partial \mathrm{t}}=\frac{\partial}{\partial \mathrm{x}}\left(\mathrm{D}_{\mathrm{ex}} \frac{\partial \mathrm{M}}{\partial \mathrm{x}}\right)$

and the appropriate initial and boundary conditions are:

$$
\begin{array}{lll}
\frac{\partial \mathrm{M}}{\partial \mathrm{x}}=0 & \mathrm{t}>0 & x=0 \\
\mathrm{M}=\mathrm{M}_{\mathrm{e}} & \mathrm{t}>0 & x=l
\end{array}
$$


$\mathrm{M}=\mathrm{M}_{\mathrm{i}} \quad t=0 \quad 0<x<l$

where $l$ is half the thickness of the slab, $\mathrm{M}_{\mathrm{i}}$ is the initial moisture content and $M_{e}$ is the moisture content at equilibrium, which might be assimilated to the moisture content when the humidity ratio at the limit of the material and that of the air flowing over the material are equivalent during some time.

Using the method of separation of variables, and applying the initial and boundary conditions, the solution is given by equation 4 (Luikov, 1968):

$\mathrm{MR}=\frac{\mathrm{M}-\mathrm{M}_{\mathrm{e}}}{\mathrm{M}_{\mathrm{i}}-\mathrm{M}_{\mathrm{e}}}=\frac{8}{\pi^{2}} \sum_{\mathrm{n}=0}^{\infty} \frac{1}{(2 \mathrm{n}+1)^{2}} \exp \left[-\mathrm{D}_{\text {eff }} \frac{(2 \mathrm{n}+1)^{2} \pi^{2} \mathrm{t}}{4 l^{2}}\right]$

Dimensional analysis showed that only the first term was valuable whereas the others might be disregarded. This leads to:

$\mathrm{MR}=\frac{\mathrm{M}-\mathrm{M}_{e}}{\mathrm{M}_{\mathrm{i}}-\mathrm{M}_{e}}=\frac{8}{\pi^{2}} \exp \left[-\mathrm{D}_{\text {eff }} \frac{\pi^{2} \mathrm{t}}{4 l^{2}}\right]$

Putting $K=\frac{\pi^{2} \mathrm{D}_{\text {eff }}}{4 l^{2}}$, equation (5) becomes:

$\mathrm{MR}=\frac{8}{\pi^{2}} \exp (-K \mathrm{t})$

$K$ is the drying constant. After taking the natural logarithm and doing some rewriting, we get the following expression:

$\ln (\mathrm{MR})=\ln \left(\frac{\mathrm{s}}{\mathrm{\pi}^{2}}\right)-K \mathrm{t}$

$K$ is the slope of the curve obtained from $\ln (\mathrm{MR})_{\exp }$ versus $t$. Then the effective diffusivity coefficient $\mathrm{D}_{\text {eff }}$, can be determined by:

$\mathrm{D}_{\text {eff }}=\frac{K}{\pi^{2}} 4 l^{2}$

The other sample configuration is a cube of $2 l$ side width. The mass balance equation (1) was given previously as a 3-D equation. The initial and boundary conditions are

$$
\begin{aligned}
& \frac{\partial \mathrm{M}}{\partial \mathrm{x}}=\frac{\partial \mathrm{M}}{\partial \mathrm{y}}=\frac{\partial \mathrm{M}}{\partial z}=0 \quad \mathrm{t}>0 \quad x=0, y=0, z=0 \\
& \mathrm{M}=\mathrm{M}_{\mathrm{e}} \\
& \mathrm{t}>0 \quad \text { on each cube face } \\
& \mathrm{M}=\mathrm{M}_{\mathrm{i}} \\
& \mathrm{t}=0 \quad 0<x<l ; 0<y<l ; 0<z<l
\end{aligned}
$$

The solution for the 3-D differential equation (1) might be obtained through the product of the 1-D solution for slabs whose intersection constitutes the cube (Luikov, 1968) :

$\frac{M(t, x, y, z)-M_{e}}{M_{i}-M_{e}}=\left(\frac{M(t, x)-M_{e}}{M_{i}-M_{e}}\right)\left(\frac{M(t, y)-M_{e}}{M_{i}-M_{e}}\right)\left(\frac{M(t, z)-M_{e}}{M_{i}-M_{e}}\right) 10$

So from the 1-D solution, the solution for the 3-D equation which is, for a cube sample after applying initial and boundary conditions and assuming that only the first term of the series is valuable:

$\frac{M(t x, y z)-M_{\theta}}{M_{1}-M_{\theta}}=\left(\frac{8}{\pi^{2}} \exp \left[-D_{\text {eff }} \frac{\pi^{2} t}{4 l^{2}}\right]\right)_{x}\left(\frac{8}{\pi^{2}} \exp \left[-D_{\text {eff }} \frac{\pi^{2} t l^{2}}{4}\right)_{y}\left(\frac{8}{\pi^{2}} \exp \left[-D_{\text {eff }} \frac{\pi^{2} t}{4 l^{2}}\right]\right)_{z}\right.$

(11) or

$\mathrm{MR}=\frac{\mathrm{M}(\mathrm{t} x \mathrm{y}, \mathrm{z} z)-\mathrm{M}_{e}}{\mathrm{M}_{\mathrm{i}}-\mathrm{M}_{\theta}}=\left(\frac{8}{\mathrm{~m}^{2}}\right)^{3} \exp \left[-3 \mathrm{D}_{\text {eff }} \frac{\pi^{2} \mathrm{t}}{4 l^{2}}\right]$

And in this case, the slope is deduced from the following relation:

$\ln (\mathrm{MR})=3 \ln \left(\frac{8}{\pi^{2}}\right)-3 K \mathrm{t}$

We observed that the slope $(3 K)$ was three times the one we obtained in the case of the slab. Mass transfer on the three faces accelerates the drying process.

\section{RESULTS AND DISCUSSION}

Figure 2 shows the temperatures recorded during every experimental run. All temperatures are around the temperatures fixed for the different tests. We observed also that the variable temperature evolves as it was prescribed i.e. the temperature is fixed at $40{ }^{\circ} \mathrm{C}$ during the first-hour step, it is fixed at $46{ }^{\circ} \mathrm{C}$ during the second step, it is fixed at $52{ }^{\circ} \mathrm{C}$ during the third period, and $60{ }^{\circ} \mathrm{C}$ during the remaining time.

Figure 3 shows velocities recorded following generated Archimedes forces. We observe that, for high temperatures i.e. temperature above $52{ }^{\circ} \mathrm{C}$, velocities get stable at the same level which is around $1.2 \mathrm{~m} . \mathrm{s}^{-1}$. However, at the temperature of $40{ }^{\circ} \mathrm{C}$, the air velocity continues to increase up to $0.65 \mathrm{~m} \cdot \mathrm{s}^{-1}$ following the expression given by equation (14) (Incropera \& De Witt, 1996): 


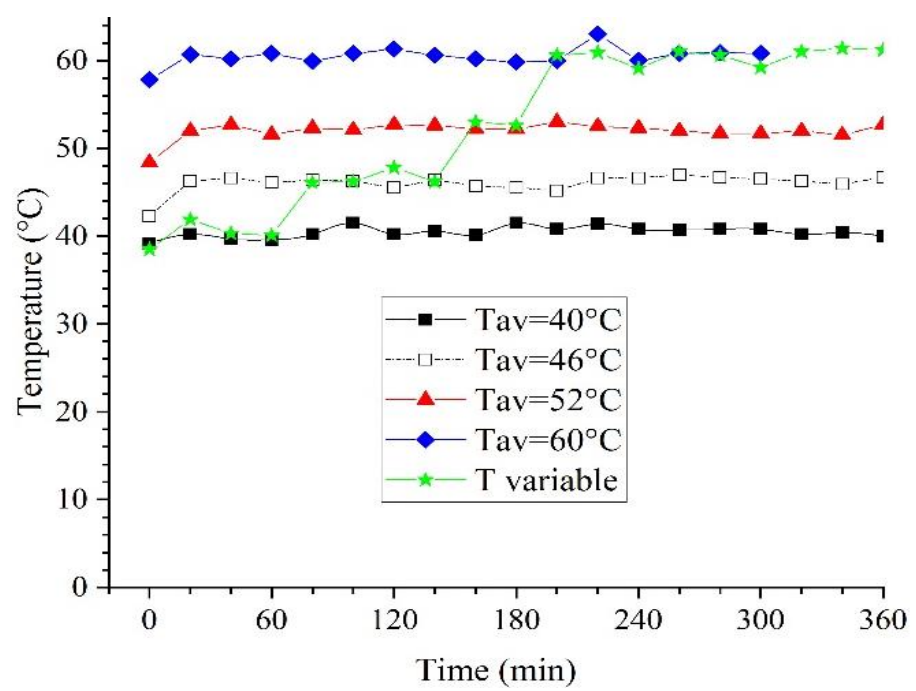

Figure 2. Recorded airflow temperatures during the drying

$v_{0}=\frac{\sqrt{2 \mathrm{~g} \rho \beta\left(\mathrm{T}_{\mathrm{H}}-\mathrm{T}_{\mathrm{g}}\right) \Delta \mathrm{H}}}{\sqrt{\mathrm{K}_{\mathrm{t}}+\mathrm{K}_{\mathrm{p}}\left(\frac{\mathrm{A}_{\mathrm{t}}}{\mathrm{A}_{\mathrm{p}}}\right)^{2}}}$

with

g: acceleration due to gravity

$\rho:$ air density

$\beta$ : expansion coefficient

$\mathrm{K}$ : friction coefficient.

A: passage area.

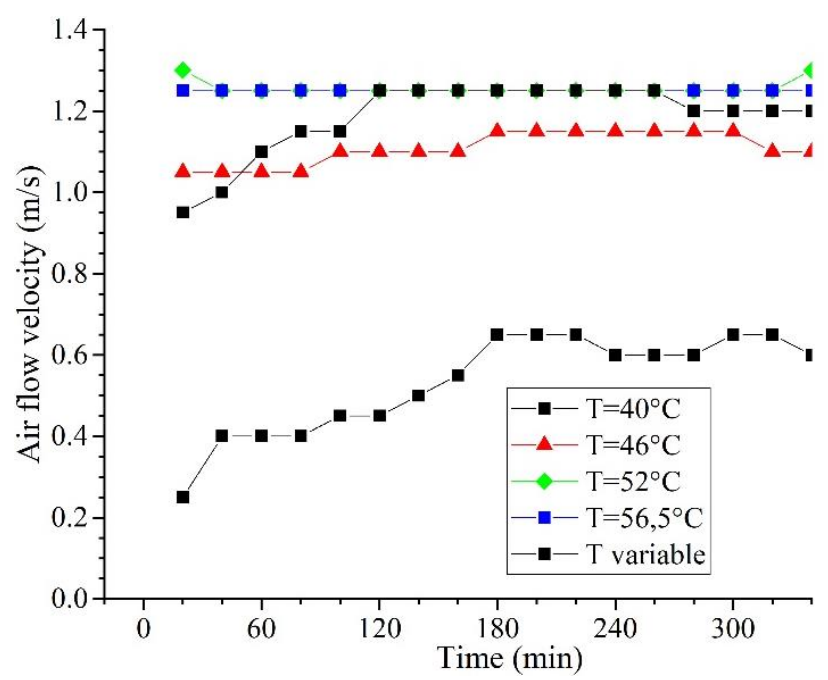

Figure 3. Recorded airflow velocities at different temperatures

In this expression, the numerator expresses the driving force achieved by the height $(\Delta \mathrm{H})$ and the temperature difference between the high temperature $\left(\mathrm{T}_{\mathrm{H}}\right)$ and the ambient temperature $\left(T_{a}\right)$ enhancing the airflow. The overall resistance due to friction through the passage area and the expansion area after the samples tray are given in the denominator. Actually, the chimney height is constant, and the temperature difference is fixed during a run, only the passage area increases because of the material shrinkage. This area increases during the whole process at low temperature. For high temperature, all parameters stabilize rapidly and the air velocity reaches $1.2 \mathrm{~m} . \mathrm{s}^{-1}$ during the whole experiment. 


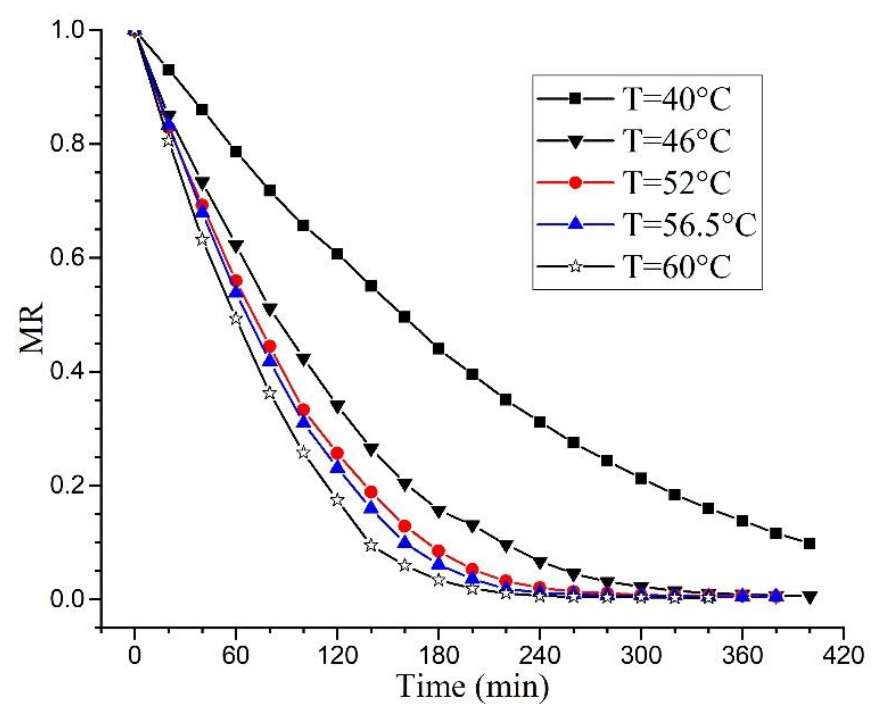

Figure 4. Moisture ratios at different temperatures for slice configuration

For airflow at varying temperature, the velocity follows the development of the driving force, i.e. mostly the temperature difference and the decrease in friction forces. Material moisture diminished with air temperature augmentation. The drying rate increases because of the increase in thermal gradients inside the material as temperature increases inducing a reduction in drying time. We observed that most of the drying process occurs during the first falling rate drying period (Figure 4 and Figure 5).

As it was predicted by mathematical analysis, the moisture ratio in cubic samples decreased more rapidly compared to the one in slice samples (Figure 5). Measurements showed that an increase in airflow temperature from $40{ }^{\circ} \mathrm{C}$ to $60{ }^{\circ} \mathrm{C}$ induced a decrease in the drying time of pumpkin slices as well as of the cubic samples. Consequently, the drying rate increased with an increase in the drying air temperature particularly during the first falling rate drying period (Figure 6).

Throughout the process, when the drying rate is near zero for samples exposed to $60{ }^{\circ} \mathrm{C}$ airflow, samples exposed to $40{ }^{\circ} \mathrm{C}$ airflow keep on yielding some moisture for a longer time. Materials dried at high temperatures undergo some shrinking which is more visible on the periphery of the product (Madamb, Driscoll \& Buckle, 1994; Ortiz-GarcíaCarrasco et al., 2015). The closure of the outside pores decelerates water mobility and holds back some moisture although the airflow velocity is higher. The phenomenon has less occurrence at low temperatures and the drying process continues. Therefore, when airflow at an increasing temperature is over the samples $40{ }^{\circ} \mathrm{C}$ for the first hour, $46{ }^{\circ} \mathrm{C}$ at the second hour, $52{ }^{\circ} \mathrm{C}$ at the third hour and $60{ }^{\circ} \mathrm{C}$ for the remaining time - it was observed that the drying time is as long as the drying time for the one when the temperature was at $60{ }^{\circ} \mathrm{C}$ during the whole run (Figure 7).

Moreover, the drying rate decreased steadily throughout the whole process for constant temperatures. On the other hand, drying rate augments at each increase in temperature then diminishes (Figure 6). Let us recall that the thickness of the cube $(10 \mathrm{~cm})$ is twice that of the slice $(5 \mathrm{~cm})$. Therefore, for the same thickness, the drying time for the cube would be a lot shorter. The consequence of this process is a lesser power consumed and less damage to some product components, which might have been caused by high temperature.

The analytical solution, given previously, assumed that the structure of the material does not change. However, most agricultural products, during drying, undergo some structural changes. Therefore, several authors (Ruhanian \& Movagharnejad 2016; Seremet, Botez, Nistor, Andronoiu \& Mocanu, 2016) came out with semi-empirical solutions; six of them which are mostly met in literature and used in forced convection drying or another form of drying. But, to the best of the authors' knowledge, the solutions have not been used in free convection drying as considered in this study (Table 1). We observed that cubic samples behaved better in drying than slab samples. Therefore, we will study in details the drying kinetic of pumpkin cubic samples. 


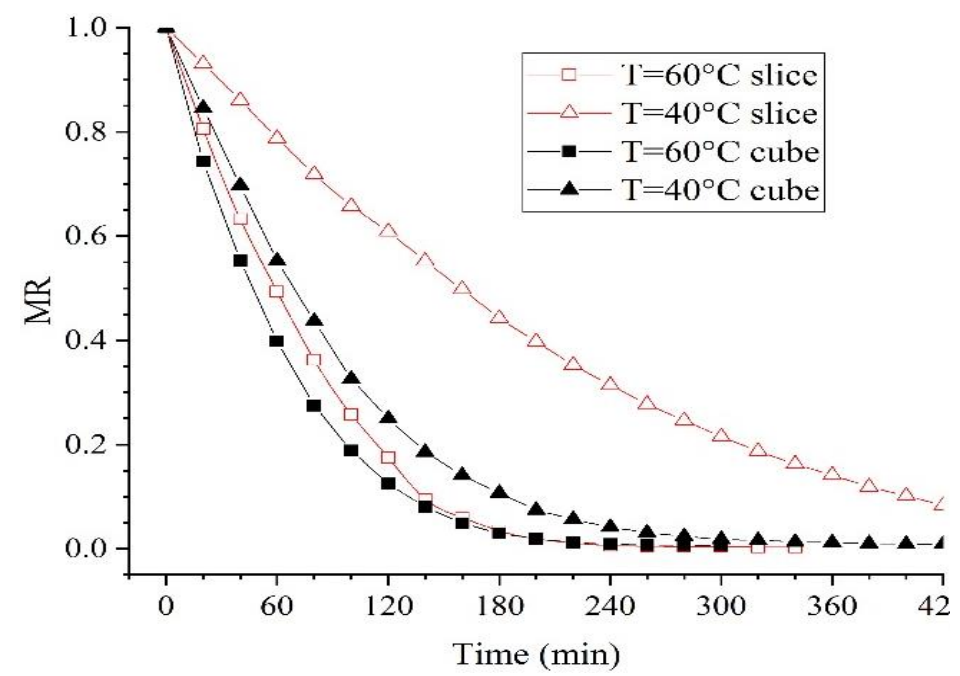

Figure 5. Moisture ratios at different temperatures for both configurations

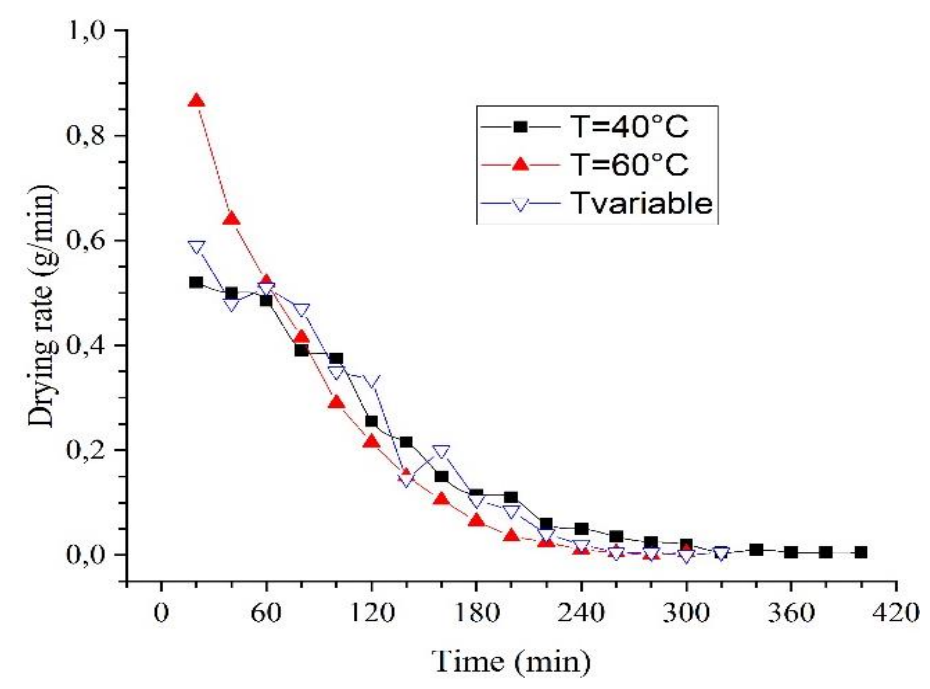

Figure 6. Drying rates at different temperatures for cubic samples

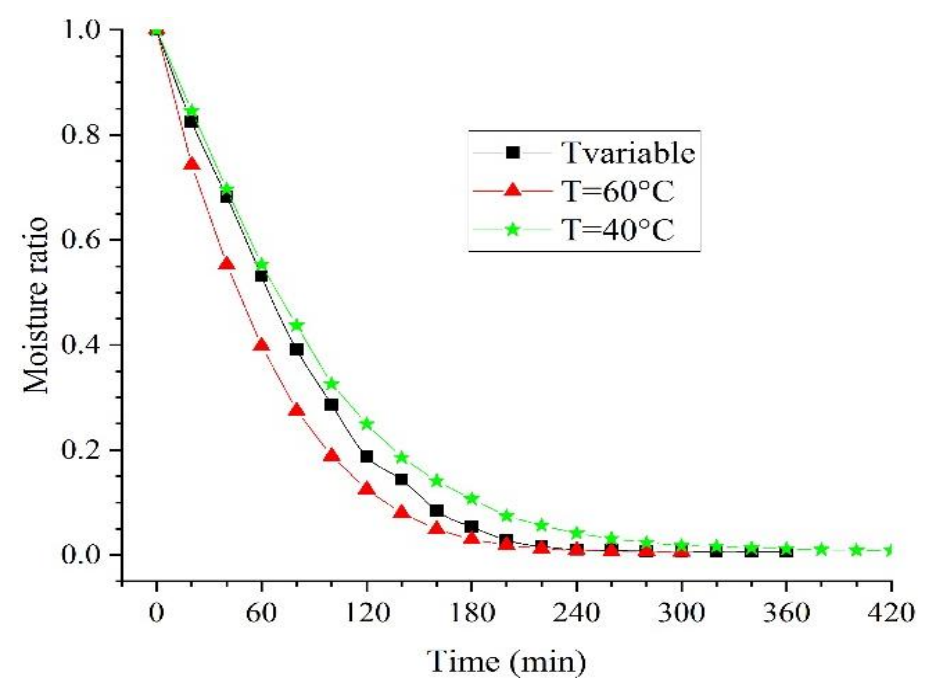

Figure 7. Moisture ratio at constant and variable temperatures for cubic configurations 
Table 1.

Mathematical expressions used to describe thin layer drying kinetics

\begin{tabular}{ll}
\hline Model name & Mathematical formulation \\
\hline Newton & $M R=\exp (-k t)$ \\
Henderson and Pabis & $M R=a \exp (-k t)$ \\
Logarithmic & $M R=a \exp (-k t)+c$ \\
Modified Page & $M R=\exp \left(-(k t)^{n}\right)$ \\
Cubic polynomial & $M R=a+b t+c t^{2}+d t^{3}$ \\
Two-term & $M R=a \exp \left(-k_{1} t\right)+b \exp \left(-k_{2} t\right)$ \\
\hline
\end{tabular}

Table 2.

Statistical results obtained for cubic pumpkin drying samples under natural convection at different temperatures

\begin{tabular}{lcccccc}
\hline Model & \multicolumn{3}{c}{$\mathbf{T}=\mathbf{4 0}^{\circ} \mathbf{C}$} & \multicolumn{3}{c}{$\mathbf{T}=\mathbf{6 0}^{\circ} \mathbf{C}$} \\
\hline Newton & $\chi^{2}$ & $\mathrm{R}^{2}$ & $\mathrm{RSS}$ & $\chi^{2}$ & $\mathrm{R}^{2}$ & $\mathrm{RSS}$ \\
Henderson and Pabis & $7.02629 \mathrm{E}-4$ & 0.99230 & 0.01405 & $3.14492 \mathrm{E}-4$ & 0.99660 & 0.00472 \\
Logarithmic & $5.16275 \mathrm{E}-4$ & 0.99463 & 0.00981 & $2.877752 \mathrm{E}-4$ & 0.99709 & 0.00403 \\
Modified Page & $3.97884 \mathrm{E}-4$ & 0.99608 & 0.00716 & $1.78456 \mathrm{E}-4$ & 0.99833 & 0.00232 \\
Cubic polynomial & $\mathbf{2 . 1 6 8 6 5 E - 5}$ & $\mathbf{0 . 9 9 9 6 8}$ & $\mathbf{3 . 9 0 3 5 7 E}-4$ & $\mathbf{5 . 2 9 3 3 6 E - 5}$ & $\mathbf{0 . 9 9 9 0 6}$ & $\mathbf{6 . 8 8 1 3 7 E - 4}$ \\
Two-term & $\mathbf{6 . 5 3 5 7 9 E - 5}$ & $\mathbf{0 . 9 9 9 3 9}$ & $\mathbf{0 . 0 0 1 1 1}$ & $\mathbf{8 . 2 1 3 6 0 E - 5}$ & $\mathbf{0 . 9 9 9 2 9}$ & $\mathbf{9 . 8 5 6 3 2 E}-4$ \\
& $5.44957 \mathrm{E}-4$ & 0.99463 & 0.00981 & $3.09886 \mathrm{E}-4$ & 0.99709 & 0.00403 \\
\hline
\end{tabular}

Table 3.

Constant and coefficient values for the modified Page model

\begin{tabular}{lccccc}
\hline Temperature & $\boldsymbol{k}$ & $\boldsymbol{n}$ & $\mathbf{R}^{2}$ & $\chi^{2}$ & RSS \\
\hline $\mathrm{T}=40{ }^{\circ} \mathrm{C}$ & 0.01088 & 1.20516 & 0.99968 & $2.16865 \mathrm{E}-5$ & $3.90357 \mathrm{E}-4$ \\
$\mathrm{~T}=60{ }^{\circ} \mathrm{C}$ & 0.01589 & 1.12786 & 0.99906 & $5.29336 \mathrm{E}-5$ & $6.88137 \mathrm{E}-4$ \\
\hline
\end{tabular}



Figure 8. Moisture ratios at constant temperatures and best-fit model for cubic configurations

Table 4.

Effective diffusivity during pumpkin drying process at different constant temperatures

\begin{tabular}{lcc}
\hline Temperature & Effective diffusivity & $\mathbf{R}^{\mathbf{2}}$ \\
\hline $40{ }^{\circ} \mathrm{C}$ & $4.42547 \mathrm{E}-08$ & 0.99312 \\
$60{ }^{\circ} \mathrm{C}$ & $6.9205 \mathrm{E}-08$ & 0.99412 \\
\hline
\end{tabular}


Table 5.

Effective diffusivity during pumpkin drying process at varying temperature

\begin{tabular}{lcc}
\hline \multicolumn{1}{c}{ Period } & Effective diffusivity & $\mathbf{R}^{2}$ \\
\hline First period $\left(\mathrm{T}=40^{\circ} \mathrm{C}\right)$ & $3.72902 \mathrm{E}-08$ & 0.99517 \\
Second period $\left(\mathrm{T}=46^{\circ} \mathrm{C}\right)$ & $5.80483 \mathrm{E}-08$ & 0.99278 \\
Third period $\left(\mathrm{T}=52^{\circ} \mathrm{C}\right)$ & $7.25182 \mathrm{E}-08$ & 0.98327 \\
Remaining time $\left(\mathrm{T}=60^{\circ} \mathrm{C}\right)$ & $9.22958 \mathrm{E}-08$ & 0.99416 \\
\hline
\end{tabular}

The empirical model best-fitted to experimental data is selected based on three statistical parameters, which are the coefficient of determination $\left(\mathrm{R}^{2}\right)$, reduced chi-square $\left(\chi^{2}\right.$, and residual sum of squares (RSS), which should be the highest coefficient for the first one and the lowest ones for the reduced chisquare and residual sum of squares (Table 2).

The modified Page model and the cubic polynomial model fit very well with the experimental data with a slight advantage to the first one (Figure 8). Accordingly, constant values for the modified Page model are generated (Table 3).

Using the slope technique, the curve of $\ln (\mathrm{MR})$ versus time lets us deduce the drying constant, which is determined from the fitted linear relation to the curve. The use of equations 13 and 8 lets us determine the effective diffusivity coefficient of pumpkin during free convection drying subjected to different temperatures (Tables 4 and 5).

Results in Table 4 show that, with an increase in temperature, the effective diffusivity coefficient increases making the product dry in a shorter time. However, as mentioned previously, high temperatures affect the material structure. In practice, the product is not at a uniform temperature.

Phase change takes place mostly on the periphery of the material and its evacuation creates some "emptiness".

The pores shrink and the vapour passage diminishes. To avoid this phenomenon, the pumpkin was dried at varying temperature airflow. It appears that, at every increase in temperature, the drying rate suddenly rises. Beginning with $40{ }^{\circ} \mathrm{C}$ up to $60{ }^{\circ} \mathrm{C}$, the process took less time than the one at $60{ }^{\circ} \mathrm{C}$ (Figure 7). Temperature increase gives rise to the effective diffusivity coefficient (Table 5). In the last step in which the temperature is 60 ${ }^{\circ} \mathrm{C}$, the effective diffusivity coefficient is much higher than the one in the process at uniform $60{ }^{\circ} \mathrm{C}$ temperature. Consequently, the effective diffusivity coefficient depends not only on the temperature but also on the material structure. Therefore, the variable temperature process consumes less energy compared to the one at $60{ }^{\circ} \mathrm{C}$ temperature. Besides when the product is under a flow of high temperature on short period, its components are much less subject to destruction.

\section{CONCLUSIONS}

The objective of the study was to find out a way to dry pumpkin in a short time, consuming less energy, and ending up with unalterable product quality. The results showed that cubic configuration of sample during drying performed better than slice configuration and high temperature made the samples dry in a shorter time. Modified Page model came out the best-fitted model to experimental data generating the highest coefficient of determination $\left(\mathrm{R}^{2}\right)$ and the lowest reduced chi-square $\left(\chi^{2}\right)$ and residual sum of squares. The effective diffusivity increased with temperature rise. The drying process under high temperature generates some shrinking of the product particularly on its periphery. This leads to pore closure, which withholds some residual moisture from leaving the product. The drying process with airflow at a gradually increasing temperature regime led to less shrinking and, consequently, to better drying, as shown by an increase in effective diffusivity coefficient at every increase in temperature. Finally, we got an optimized process modelled by the modified Page model, in which the product samples had a cubic shape, and the airflow temperature increased stepwise. This led to a shorter drying time, less energy consumption and better product appearance. This process might be used to dimension and simulate solar energy conversion systems since these deliver an airflow temperature, which depends on solar radiation intensity. It might be also used 
in a conventional dryer to reduce energy consumption.

\section{ACKNOWLEDGEMENT}

The authors declare that they have no conflict of interest.

\section{REFERENCES}

Arévalo-Pinedo A., \& Murr F.E.X. (2007). Influence of pre-treatments on the drying kinetics during vacuum drying of carrot and pumpkin. Journal of Food Engineering, 80,152-156. https://doi.org/10.1016/j.jfoodeng.2006.05.005

Bantle M., Käfer T., \& Eikevik T.M. (2013). Model and process simulation of microwave assisted convective drying of clipfish. Applied Thermal Engineering, 59, 675-682.

https://doi.org/10.1016/j.applthermaleng.2013.05.046

Bouhdjar A., Semai H., Boukadoum A., El Mokretar S., Mazari A., Semiani M., \& Amari A. (2020). Improved procedure for natural convection garlic drying. Acta Technologica Agriculturae, 2, 92-98. https://doi.org/10.2478/ata-2020-0015

Crank J. (1979). The mathematics of diffusion. Great Britain: Oxford Press.

Crapiste G.H., Whitaker S., \& Rotstein E. (1988). Drying of cellular material - I. A mass transfer theory. Chemical Engineering Science, 43, 29192928.

Doymaz I. (2007). The kinetics o

$\mathrm{f}$ forced convective air-drying of pumpkin slices. Journal of Food Engineering, 79, 243-248. https://doi.org/10.1016/j.jfoodeng.2006.01.049

Esturk, O., \& Soysal, Y. (2010). Drying properties and quality parameters of dill dried with intermittent and continuous microwave-convective air treatments. Journal of Agricultural Science, 16, 26-36.

Incropera F.P., \& De Witt D.P. (1996). Introduction to heat transfer (3rd ed). New York: Wiley.

Kocabiyik H. (2010). Combined infrared radiation and hot air drying. In Z. Pan \& G.G. Atungulu (Eds.), Infrared Heating for Food and Agricultural Processing (pp. 101-116). CRC Press Taylor \& Francis Group.

Luikov A.V. (1968). Analytical heat diffusion theory. New York, London,Toronto, Sidney, San Francisco: Academic Press.
Madamb P.S., Driscoll R.H., \& Buckle K.A. (1996). The thin layer drying characteristics of garlic slices. Journal of Food Engineering, 29, 75-97.

Nawirska A., Figiel A., Kucharska A.Z., Sokol-Letowska A., \& Biesiada A. (2009). Drying kinetics and quality parameters of pumpkin slices dehydrated using different methods. Journal of Food Engineering, 94, 14-20. https://doi.org/10.1016/j.jfoodeng.2009.02.025

Ortiz-Garcia-Carrasco B., Yanez-Mota E., Pachecoaguirre F.M., Ruiz-Espinosa H., Garcia-Alvarado M.A., Cortes-Zavaleta O., \& Ruiz-Lopéz I.I. (2015). Drying of shrinkable food products: Appraisal of deformation behavior and moisture diffusivity estimation under isotropic shrinkage. Journal of Food Engineering, 144, 138-147. https://doi.org/10.1016/j.jfoodeng.2014.07.022

Perez N.E., \& Schmalko M.E. (2009). Convective drying of pumpkin: influence of pre-treatment and drying temperature. Journal of Food Process Engineering, 32, 88-103. https://doi.org/10.1111/j.1745-4530.2007.00200.x

Roongruangsri W., \& Bronlund J.E. (2015). A review of drying processes in the production of pumpkin powder. International Journal of Food Engineering, 11, 789-799. https://doi.org/10.1515/ijfe-2015-0168

Ruhanian S., \& Movagharnejad K. (2016). Mathematical modeling and experimental analysis of potato thin-layer drying in an infrared-convective dryer. Engineering in Agriculture, Environment and Food, 9, 84-91. https://doi.org/10.1016/j.eaef.2015.09.004

Seremet L., Botez E., Nistor O.V., Andronoiu D.G., \& Mocanu G.D. (2016). Effect of different drying methods on moisture ratio and rehydration of pumpkin slices. Food Chemistry, 195, 104-109. https://doi.org/10.1016/j.foodchem.2015.03.125

Süfer, Ö., Sezer, S., \& Demir, H. (2017). Thin layer mathematical modeling of convective, vacuum and microwave drying of intact and brined onion slices. Journal of Food Processing and Preservation, 41. https://doi.org/10.1111/jfpp.13239

Tunde-Akintunde T.Y., \& Ogunlakin, G.O. (2013). Mathematical modeling of drying of pretreated and untreated pumpkin. Journal Food Science and Technology, 50, 705-713. https://doi.org/10.1007/s13197-011-0392-2 


\title{
POBOLŠANI PROTOKOL ZA PRIRODNO KONVEKTIVNO SUŠENJE BUNDEVE
}

\author{
Hakim Semai, Amor Bouhdjar*, Aissa Amari \\ Centar za razvoj obnovljive energije (CDER), Odeljenje za solarnu toplotnu i geotermalnu energiju, 16340 \\ Bouzareah Alžir, Alžir.
}

Sažetak: Najefikasniji način očuvanja poljoprivrednog proizvoda je sušenje. Međutim, sušenje povrća je postupak koji troši energiju. U ovom radu, razmatra se konvektivno sušenje bundeve ca ciljem iznalaženja režima sušenja koji smanjuje vreme sušenja i minimizira potrošnju toplote. $U$ radu se razmatra i uticaj konfiguracije uzorka na efikasnost sušenja i ispituju se uzorci bundeve u obliku kriške i kocke. Uzorci su podvrgnuti protoku vazduha sa slobodnom konvekcijom na različitim temperaturama $\left(40^{\circ} \mathrm{C}\right.$, $46^{\circ} \mathrm{C}, 52^{\circ} \mathrm{C}$ i $60^{\circ} \mathrm{C}$ ) za svaku seriju. Takođe je uzet u obzir i režim sušenja sa promenljivom temperaturom vazdušne struje. Krive sušenja su fitovane korišćenjem široko upotrebljavanih modela kod modelovanja tankoslojnog sušenja. Eksperimentalni podaci su se najbolje uklapali u izmenjeni Pejdžov model. Efektivni koeficijent difuzivnosti određen je za svaku seriju preko nagiba krive promene sadržaja vlage. Pokazalo se da je difuzivnost velika, a vreme sušenja kratko za ispitivane visoke temperature sušenja. Procesi sušenja za uzorke bundeve u obliku kocke bili su efikasniji u odnosu na one u obliku kriške. Pri primeni režima sušenja sa promenljivom temperaturom vazdušne struje na uzorke bundeve u obliku kocke, analiza podataka pokazala je da je efektivna difuznost bila veća u trećoj fazi u poređenju sa svim ostalim ispitivanim temperaturama sušenja, dok je ukupno vreme sušenja bilo je slično onom dobijenom u režimu sušenja na visokoj temperaturi. Ovim postupkom ukupno potrošena energija bila je mnogo manja, a vreme sušenja kraće.

Ključne reči: slobodan protok vazduha, optimizacija energije, konfiguracija uzorka, povrće, Page model, difuzivnost

Received: 16 March 2021/Received in revised form: 31 May 2021/ Accepted: 03 June 2021

Available online: June 2021

This is an open-access article under the CC BY license (http://creativecommons.org/licenses/by/3.0). 